\section{Curing What Ails Us}

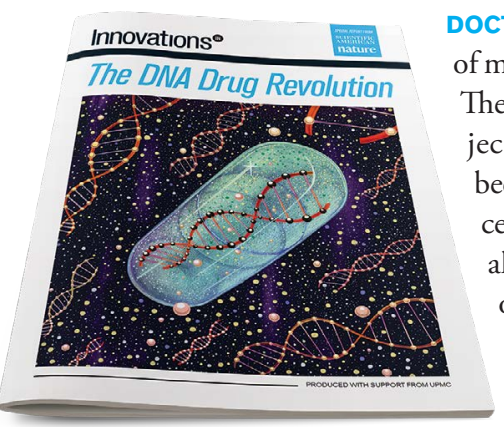

DOCTORS HAVE BEEN TREATING THE SYMPTOMS of most diseases, and not the source, for centuries. They have cut out tumors, unclogged arteries, injected insulin and soothed fevers-and have been unable to touch the biological code within cells that tells them to grow malignantly, pass along abnormal nerve signals, take in too much or too little energy, and swell with inflammation. The code is the DNA molecule in each cell that tells it what to do and when, and it triggers dreaded diseases when it goes wrong. The molecule, and its messengers, had remained tucked away, beyond the reach of almost all drugs, unfixable when broken. But as this special report explains, that is no longer the case.

Things began to change after the DNA sequence for the entire human genome was laid out early in this century, and within the past several years the ability to synthesize and custom-design shorter sequences has shown scientists that the best substance for reaching DNA is, well, DNA. Fabricating new genes to replace badly working versions, or to "silence" them, has produced 14 approved DNA-related drugs (page S12). And the latest research indicates that such therapies can be even more effective if scientists depart from the basic linear strands and instead make DNA spheres, which have enhanced abilities to enter cells (page S3). DNA analysis has also yielded new targets, showing that although newborn babies in the U.S. are typically screened for between 30 and 60 genetic conditions right now, it is possible to find nearly 1,000 genes linked to childhood diseases that could be new treatment points (page S8).

But that same science has also created troubling issues: some of the gene tests for infants can raise false alarms, for instance, and not every child with a disease-associated gene ends up getting that disease. Research has also revealed unfair bias in DNA targets. Most of the data about those sequences comes from studies of white people and has missed gene variants that cause disease in nonwhites - inequality in research that will produce inequality in health if it isn't fixed ( page S14). Geneticists are starting projects designed to improve this diversity level. DNA in medicine has great power, and that power should be used for the many, not the few.

This report on DNA drugs and related therapies, which is being published in Scientific American and Nature, is sponsored by UPMC. It was produced independently by Scientific American editors, who have sole responsibility for all editorial material. UPMC agreed to sponsor this topic but had no input into the content.

Josh Fischman Senior Editor

\section{S3 The Power of Spheres}

DNA or RNA molecules, arranged into spherical shapes, can attack brain cancers and other illnesses that evade conventional drug design.

By Chad A. Mirkin, Christine Laramy and Kacper Skakuj

\section{GRAPHIC: DNA TO TREAT DNA}

\section{S8 23 and Baby}

We now have the ability to screen for thousands of genetic diseases in newborns. That may not always be a healthy thing to do. By Tanya Lewis

\section{S12 Gene Therapy Arrives}

After false starts, drugs that manipulate the code of life are finally changing lives. By Jim Daley

\section{S14 All of Us}

DNA-based medicine needs more diversity to avoid harmful bias. One big research project is beginning to fix that. By Stephanie Devaney

\section{EDITORIAL}

ACTING EDITOR IN CHIEF Curtis Brainard

CHIEF FEATURES EDITOR Seth Fletcher

SENIOR EDITOR

Josh Fischman
CREATIVE DIRECTOR Michael Mrak

SENIOR GRAPHICS EDITOR Jen Christiansen

ASSOCIATE GRAPHICS EDITOR Amanda Montañez
COPY DIRECTOR Maria-Christina Keller

SENIOR COPY EDITORS Daniel C. Schlenoff, Aaron Shattuck, Angelique Rondeau 